\title{
10th Street Substation Excavation of the Acequia Madre (41BX8), San Antonio, Bexar County, Texas
}

I. Waynne Cox

Follow this and additional works at: https://scholarworks.sfasu.edu/ita

Part of the American Material Culture Commons, Archaeological Anthropology Commons, Environmental Studies Commons, Other American Studies Commons, Other Arts and Humanities Commons, Other History of Art, Architecture, and Archaeology Commons, and the United States History Commons

Tell us how this article helped you.

This Article is brought to you for free and open access by the Center for Regional Heritage Research at SFA ScholarWorks. It has been accepted for inclusion in Index of Texas Archaeology: Open Access Gray Literature from the Lone Star State by an authorized editor of SFA ScholarWorks. For more information, please contact cdsscholarworks@sfasu.edu. 
10th Street Substation Excavation of the Acequia Madre (41BX8), San Antonio, Bexar County, Texas

\section{Creative Commons License}

\section{(c) (1) \&}

This work is licensed under a Creative Commons Attribution-NonCommercial 4.0 International License 


\section{Waynne Cox}

Texas Antiquities Committee Permit No. 441 Dr. Thomas R. Hester, Principal Investigator

Center for Archaeological Research The University of Texas at San Antonio ${ }^{\circledR}$ Archaeological Survey Report, No. 153 
The following information is provided in accordance with General Rules of Practice and Procedure Chapter 41.11 (Investigation Reports), Texas Antiquities Committee:

1. Type of Investigation: Historical and Archaeological, Acequia Madre at the CPS 10th Street Substation in San Antonio, Texas;

2. Project Name: Acequia Madre (4I BX 8) at loth Street Substation;

3. County: Bexar County, Texas;

4. Principal Investigators: Thomas R. Hester, Principal Investigator; I. Waynne Cox, Field Director;

5. Name and Location of Sponsoring Agency: City Public Service, San Antonio, Texas;

6. Texas Antiquities Committee Permit No. 441;

7. Published by the Center for. Archaeological Research, The University of Texas at San Antonio, San Antonio, Texas 78285, 1985.

A 1 ist of publications offered by the Center for Archaeological Research can be obtained by sending $\$ 1.00$ to the Center for Archaeological Research. The University of Texas at San Antonio, San Antonio, Texas 78285. 


\section{ABSTRACT}

The acequias or irrigation systems were an important factor in the early history of San Antonio. One of the earliest of these was the Acequia Madre (41 BX 8) or Mother Ditch. Recently, proposed construction by City Pub 1 ic Service at the loth Street Substation was expected to encounter the course of the acequia, thus requiring archaeological investigation. Excavation of a section of the acequia with a backhoe and archival research revealed new information about the history of this ancient waterway. 
TABLE OF CONTENTS

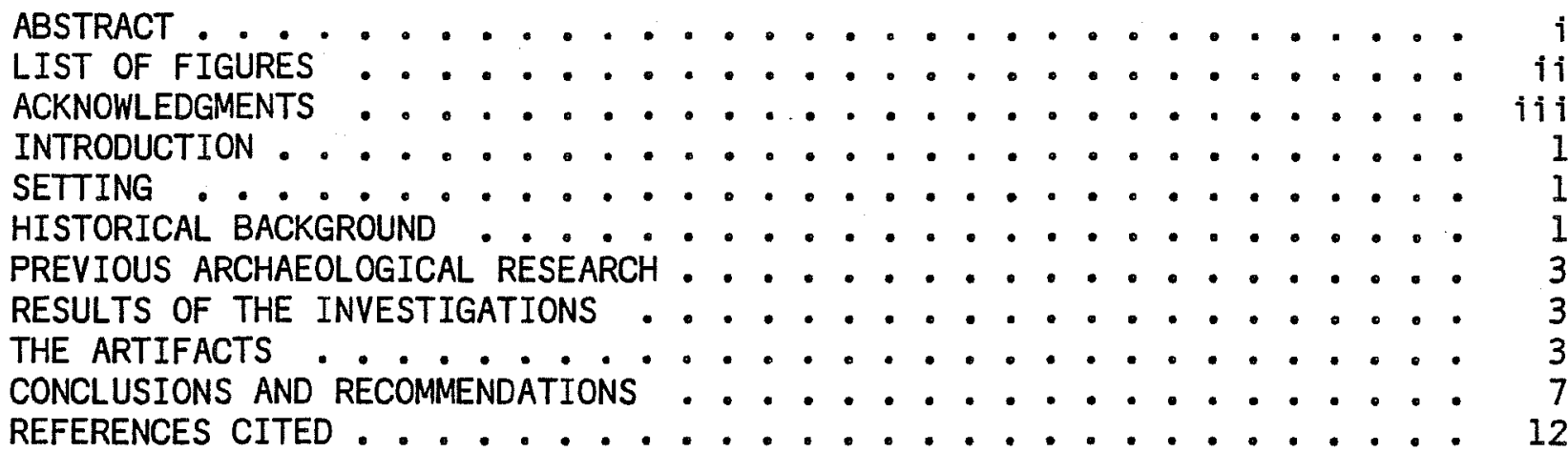

LIST OF FIGURES

1. Map of the Project Area Indicating Location of the Acequia Madre

(41 BX 8)

2. South Soil Profile of the Backhoe Trench Across the Acequia Madre at the loth Street Substation ................

3. Selected Ceramic and Metal Artifacts from the Acequia Madre at the IOth Street Substation . . . . . . . . . . . . . .

4. Selected Glass Artifacts from the Acequia Madre at the 10th Street Substation ... . . . . . . . . . . . . . . . . . 


\section{ACKNOWLEDGMENTS}

I would 7 ike to thank Cindy Soule and the backhoe crew from City Public Service; their help and cooperation allowed us to gain the maximum amount of information in a minimum amount of time. I would also 1 ike to thank Bruce Mergele for the valuable information he supplied on storm drain construction. Thanks to my wife, Darla, again, for volunteering for a very dirty screening job. 



\section{INTRODUCTION}

On October 10, 1984, an archaeological team from the Center for Archaeological Research (CAR), The University of Texas at San Antonio (UTSA), monitored the excavation of a cross section of the historic Acequia Madre. The excavation was located midway in New City Block 516, between 9 th and 10th Streets, downtown San Antonio, Texas. The investigation was requested by City Public Service (CPS) and was done under the Texas Antiquities Committee Permit No. 441. The purpose of the investigation was to see if the acequia still remained in the planned development area and to note its construction and contents.

The investigation was conducted by Waynne Cox, Research Associate, and Ralph Snavely and Ray Smith. Technical Staff Assistants, under the supervision of Dr. Thomas R. Hester, Director of the Center for Archaeological Research, and Jack D. Eaton, Associate Director.

The acequia was cross sectioned by a CPS backhoe under the supervision of the CAR-UTSA team. An unlined ditch was found under 2-1/2 feet of pavement and fi11. The interior of the ditch contained artifacts dating from the 18705 to the 1930s. All field records and artifacts are on file at the CAR-UTSA.

\section{SETTING}

The CPS Substation, a subsidiary of the main CPS power station, is located in the northeast part of downtown San Antonio, three blocks east of the San Antonio River. The site is bounded on the north by 10 th Street, on the east by Austin Street, on the south by 9 th Street, and on the west by Alamo street. At the present time the area is covered with transformers and CPS buildings that have been constructed at various times since CPS acquired the property in 1921.

\section{HISTORICAL BACKGROUND}

In 1718 an expedition composed of Spanish soldiers and missionaries arrived at San Pedro Springs to relocate Mission San Antonio de Valero from the Rio Grande to the San Antonio River valley. Later a presidio and smal1 sett lement were established, known as Villa de Bejar ( 1 ater to be called San Antonio; Fox 1979:2; Frkuska 1981:1). One of the first considerations was the availability of water in a semiarid environment, therefore, almost immediately work was begun on construction of a system of acequias (water ditches) to irrigate the valley (Castañada 1936:96). It is thought that the first major acequia constructed was the Acequia Madre in 1724 to water the 1 ands of Mission San Antonio de Valero (the Alamo; Barker 1929:36-38). The acequia began below the headwaters of the San Antonio River and extended along what is now the east side of Broadway Avenue near the Witte Museum. It then progressed southward, roughly parallel to Broadway, to what is now the intersection of Nacogdoches and E7m Streets. There it was divided into two channels, one branch following the present route of Nacogdoches Street and to the grounds of the mission, flowing behind the chapel, and the other channel roughly following the present route of $E 1 \mathrm{~m}$ Street. The two branches joined 
where Hemisfair Plaza is now located and proceeded south along the present route of Alamo Street to the river below the present-day Pioneer Flour Mill (Fox 1979:5, 10; Bexar County P1ats; Sanborn Map and Pub 1ishing Company, Ltd. 1904 ).

As the area watered by the Acequia Madre began to develop into residential housing, its original function for irrigation shifted to public water supp $7 y$. In 1838 the City Counci 1 passed an ordinance to appoint a committee to attend to ". . a cleaning of the ditch which runs through town ..." (CCM Vol. I:31). In January 1840 the "ditch of the Alamo" was included in the provisions of this ordinance, and a separate general superintendent, or commissioner, was appointed (CCM Vol. I:37). In January 1852 a contract was issued,

- . for constructing a ditch across the Main Plaza in 1 ine of the present dilapidated one of the following dimensions, three feet wide at the bottom and four feet wide at the top, solid masonery (sic) of stone 1 aid in sand and 1 ime. Wall eighteen inches thick to be paved at the bottom with flat stone. Excavated and completed the surplus dirt to be deposited in the old or present ditch... (CCM VoT. II:158)

This was apparently the beginning of the practice of 1 ining portions of the acequia system with stone. In 1857 several property owners complained to the City Council on the condition of the Alamo Ditch, stating,

- . said ditch is totally out of repair so that it answers no useful purpose at all but on the contrary being partially dry and the water in a stagnant condition is a source of sickness to those living on or near its banks (CCM Vol. III:41).

In December of that same year, W. A. Menger was paid $\$ 336.69$ for improving and reopening the $A 1$ amo Ditch (CCM Vol. II:97). In 1866 an ordinance was passed requiring that all branch ditches running through the streets be walled on both sides (CCM Vol. III:519). In January 1867 preparations were made for the opening of a new branch called the Valley Ditch which extended from the Alamo Ditch at the location of present-day 8th Street. The condition of the dam and the double water gates, and that portion of the A 1 amo Ditch, were inspected by the City Council and found to be basically sound (CCM Vol. III:580). It is quite likely that any un lined sections of the acequia were 1 ined at that time from 9 th Street to the return to the river. Bills presented to the City Council indicate that repairs and cleaning were regularly conducted until at least 1885 (CCM Vol. V:181, 200, $217,311,530,590 ; \mathrm{V} 01$. VI:520). Deed records indicate that the ditch was partially open as 1 ate at 1891 (BCDR Vol. 90:409). An article in the Daily Express stated that it was sti11 in use in July 1893 (Everett 1975:13). By 1909 the southern portion of the system was converted to storm drainage (CPS n.d.; City Pub 1 ic Works 1924).

The 7 and where this portion of the acequia under investigation is located was part of the original grant from the King of Spain in 1733. This grant was cal led the Ejidos or City Grant. In March 1845 this 1 and, along with five other town 1ots, was conveyed by the mayor of San Antonio to Samuel Maverick. 
His heirs, Wil 1 iam H. Maverick and Louise Caroline Kendel 1, replatted the subdivision and sold this property to the San Antonio Street Railway in June 1881 and May 1882. City Pub1 ic Service acquired the 1 and in 1921 (Texas Report VII 1851 Vo1. 7:288-322; BCDR Vol. H1:347, Vo1. 19:280, Vol. 663:382).

\section{PREVIOUS ARCHAEOLOGICAL RESEARCH}

The first excavations of the Acequia Madre were done by the Texas Historical Survey Committee in collaboration with the Witte Museum. The excavations were located in what is now HemisFair Plaza and the Zilker property on Starr Street in 1966 and 1968, respectively (Schuetz 1970:3-17). In 1970 the Texas Archeological Salvage Project excavated a section of the Acequia Madre on the grounds of the ATamo (Sorrow 1972). In 1973 the CAR-UTSA excavated a sma 11 portion of the same acequia on the north side of the Alamo grounds (Adams and Hester 1973). In each investigation the Acequia Madre was found to be 1 ined with stone. In 1983 Anne Fox investigated a portion of the acequia on the south side of HemisFair Plaza, and it also was found to be 1 ined with stone (Fox, personal communication). Other CAR-UTSA projects that have investigated the acequia system of the San Antonio River valley include Fox (1978, 1979), Katz (1978), Ivey (1978), Frkuska (1981). In 1981 the State Department of Highways and Pub 1 ic Transportation examined a portion of an un 1 ined acequia on the south side of Mission San Jose (Henderson and Clark 1984 ).

\section{RESULTS OF THE INVESTIGATIONS}

One area of the 10th Street Substation, 192 feet north of 9 th Street and near the property's east fence line, was selected for study. A 24-inch wide, 18foot 1 ong backhoe trench was excavated to a depth of eight feet (Fig. 1) in this impacted area. The revealed acequia was an unlined, shallow ditch approximately 15 feet wide and five feet deep at the time it was filled. The profile indicated that at one time the channel was as wide as 21 feet. This extreme width probably reflects meandering and rechannelization of the ditch during its long use. The artifacts found in the fill indicate several episodes of dumping activity, with the bulk of the artifacts concentrated in the smaller ditch of the profile (Fig. 2).

\section{THE ARTIFACTS}

Due to the mass of materials encountered (primarily concentrated in the upper fi11; see Fig. 2), and the 1 imitations of time, approximately three cubic yards of fill was screened, and only diagnostic artifacts were retained for curation. A massive amount of unidentifiable rusted iron, broken glass, bricks, etc.s were discarded. Only objects that appeared to have some value toward identification of site function or dating were retained. The ceramics, glass, and other artifacts were found to be typical of collections recovered from previous excavations of the acequia, dating from the period of the late 1800 s to early 1900s. Similar artifact collections have been described in detail by Schuetz (1970) and Frkuska (1981). The quantities and types of artifacts collected are 1 isted below. 


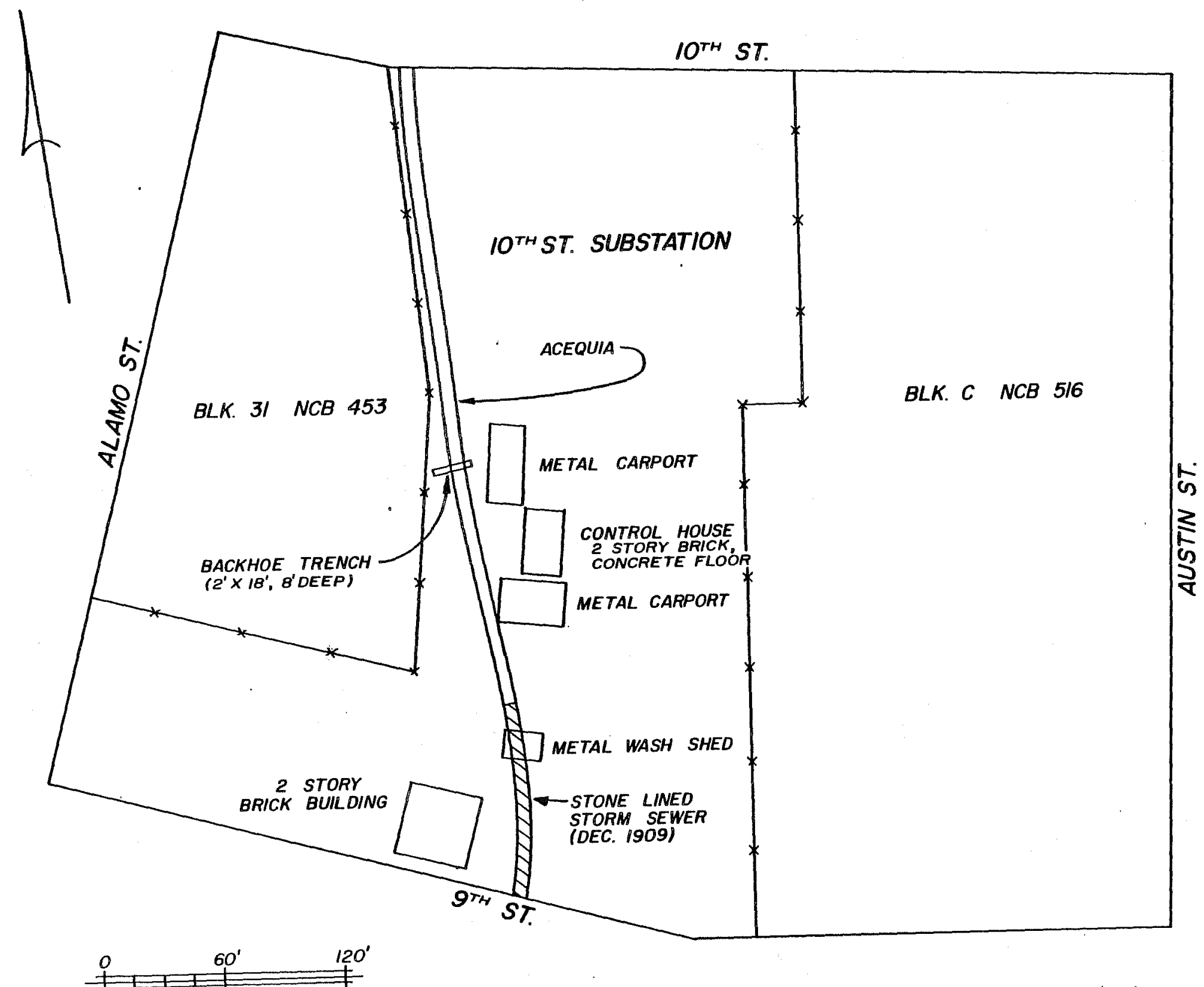

Figure 1. Map of the Project Area Indicating Location of the Acequia Madre (41 BX 8 ). 
MODERN GROUND SURFACE
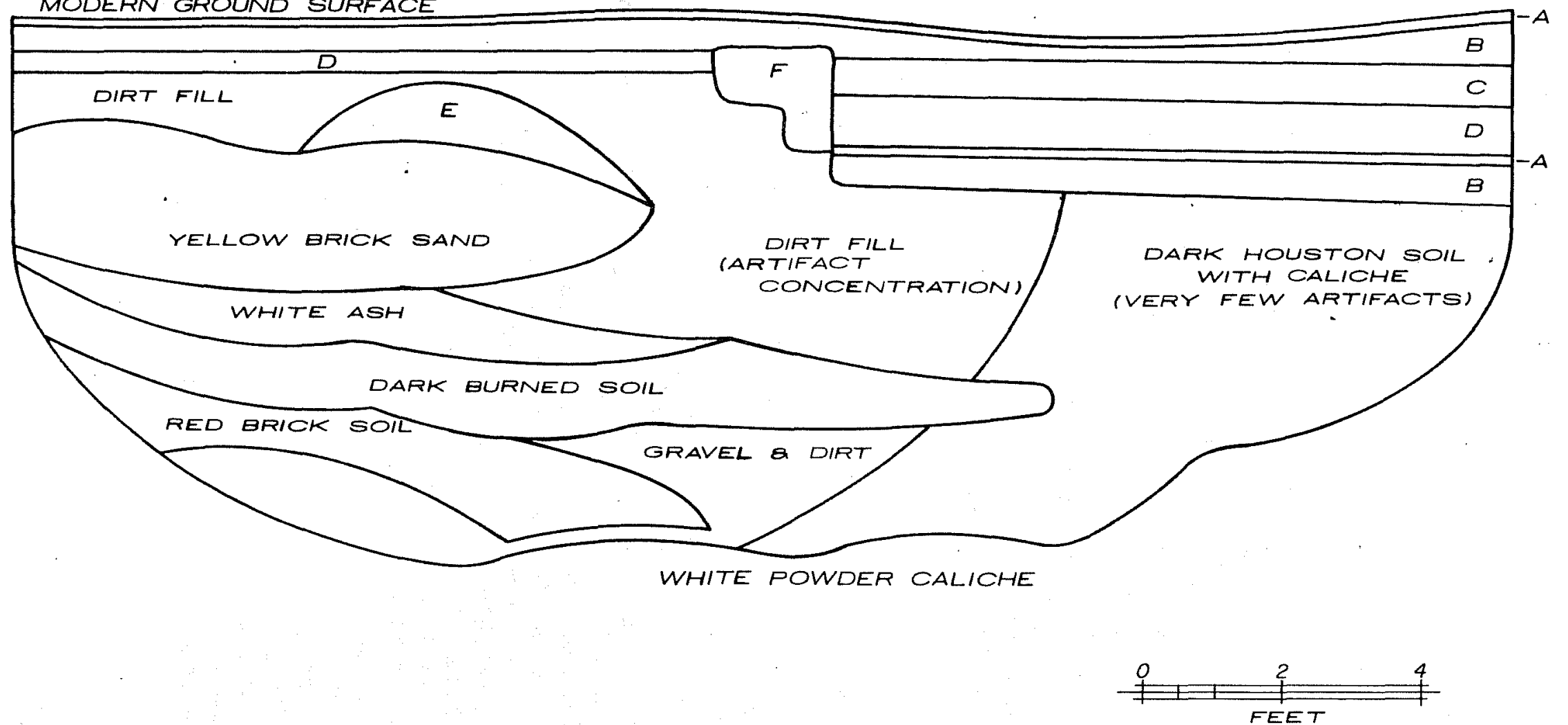

\section{LEGEND:}
A. ASPHALT
B. CLEAN CALICHE FILL
C. GRAY CLAY FILL
D. CALICHE DIRT FILL
E. BURNED BLACK ASH
F. CONCRETE BEAM

Figure 2. South Soil Profile of the Backhoe Trench Across the Acequia Madre at the 10th Street Substation. 


\section{Ceramics}

29 fragments of undecorated whiteware.

4 fragments of porcelain.

7 fragments of gold-decorated ironstone pitcher (Fig. 3,b,c).

1 fragment of a transfer print plate or saucer.

1 fragment of hand-painted porcelain.

1 fragment of a decal-decorated porcelain plate (Fig. $3, a$ ).

I fragment of luster decoration on porcelain (Fig. $3, d$ ).

I fragment of yellow ware with Rockingham glaze.

2 stoneware crock fragments, one a base fragment with the fol 1 owing: ". . comb/. . ware Co./. . comb" (McComb Stoneware Co., McComb I11 inois; Fig. 3,e).

2 stoneware ink bottle fragments, one with "Vitreous Stone Bottles/J. Bourne \& Son/Patentees/Denby Pottery/near Derby/P \& J Arnold/ London/Engl and" (Fig. 3,f).

5 porcelain electrical insulators.

1 porcelain and brass electric lamp base for screw-in bulb.

\section{Glass}

I entire clear taper-sided condiment bottle 5-3/8 inches high (Fig. $4, g$ ).

1 entire extruding shoulder clear bottle with sides tapering to square base $3-3 / 4$ inches high ( $F i g .4, e$ ).

1 entire clear milk or cream bottle, square with truncated corners 6-3/4 inches high (probably post 1880s; Fig. 4,j).

1 brown-shouldered long neck bottle produced in two-piece mold, seam extends on 1y to base of $1 \mathrm{ip}, 11-1 / 2$ inches high, bottom marked "C $M$ Co./F 28" (probab 1 y 1880-1900; Fig. $4, h$ ).

1 entire brown-shouldered long neck bottle, machine made in turn mold with crown cap, 11-1/2 inches high (probably 1892-1900; Fig. 4, i).

1 broken aqua-shouldered short neck bottle with molded 1 ip, produced in two-piece mold (probably 1880-1900; Fig. 4,f).

I brown square bottle with screw cap, 4-1/2 inches high, marked "P M/F S Co." on bottom (Fig. $4, \mathrm{k}$ ).

1 fragment round cobalt blue bottle.

1 fragment square aqua bottle produced in two-piece mold.

2 neck fragments of small molded bottles, 1 clear, 1 aqua ( $F$ ig. $4, c, d$ ).

1 fragment ointment jar.

2 fragments lamp chimney.

2 fragments of pressed glass tumbler.

2 goblet base fragments, clear (Fig. 4,a).

1 fragment aqua telephone pole insulator (Fig. $4, b$ ).

\section{Metal}

1 top of fire hydrant.

1 oil can (Fig. $3, g$ ).

3 spikes.

1 bolt. 
5 pieces of wire.

1 brass gas connection.

1 horseshoe (Fig. $3, h$ ).

1 iron pipe section, possibly holder for carbon rod.

5 pieces unidentified metal scrap.

\section{Miscellaneous}

1 sheet mica, probably from a viewing port in an iron oven, 4 inches $x$ $1-3 / 4$ inches.

1 composition comb fragment.

1 glass marble.

1 graphite electrical brush, 3-1/8 $\times 2-5 / 8 \times 5 / 8$ inches.

2 carbon rods, $1 / 2-i$ inch in diameter.

1 fragment composition rubber circular object, 7 inches in diameter with 3/4-inch hole at center, 7/8-inches thick.

The artifacts from the acequia at 10th Street reflect the usual pattern to be expected, as reflected by previous acequia excavations of a similar nature and time period (Schuetz 1970; Frkuska 1981). During its useful 1 ifetime, the periodic cleaning and repair of the acequia removed virtually all artifacts of that period. Only after the acequia ceased to fulfill its intended purpose did trash begin to accumulate. The ceramics and glass reflect an accumulation beginning no earlier than the late 1800s, and more 1 ikely, the early part of the 20 th century. The metal and miscel 1 aneous materials appear to be even later. The electrical materials most 1 ikely date to the period after the 1 and was in the possession of the San Antonio Street Railway (1881-1882), or more likely, City Public Service (1921). After reviewing the historic records, the artifact deposition probably occurred during the period from 1885 to the middle 1920 s.

\section{CONCLUSIONS AND RECOMMENDATIONS}

The Acequia Madre played a long and vital role in the history of San Antonio. The transition of its use from irrigation to water supply then to drainage is a direct reflection of the changes and growth patterns of the city. The fact that no 18th-century artifacts were recovered can be explained by the early low-density occupation in the area and the periodic cleaning of the ditches. The other acequia excavations in San Antonio reflect the same pattern of deposition, with trash beginning to accumulate only after the ditch no longer served a function, eventually being sealed (Schuetz 1970:7; Frkuska 1981:45).

It is probable that the remainder of the acequia is intact throughout the study area, and may include the transitional portion of the acequia where an open ditch was initially lined with stone. The stone lining is known to extend at least to the Hemisfair grounds. Should any future construction be planned for the 10th Street Substation area, consideration should be given to further archaeological investigation, especially in that area where the transition from open ditch to a stone-1 ined ditch might occur. During any future developments, the acequia (41 BX 8), a historic cultural resource, should be considered in the early planning stages and be protected. 
Figure 3. Selected Ceramic and Metal Artifacts from the Acequia Madre at the 10th Street Substation.

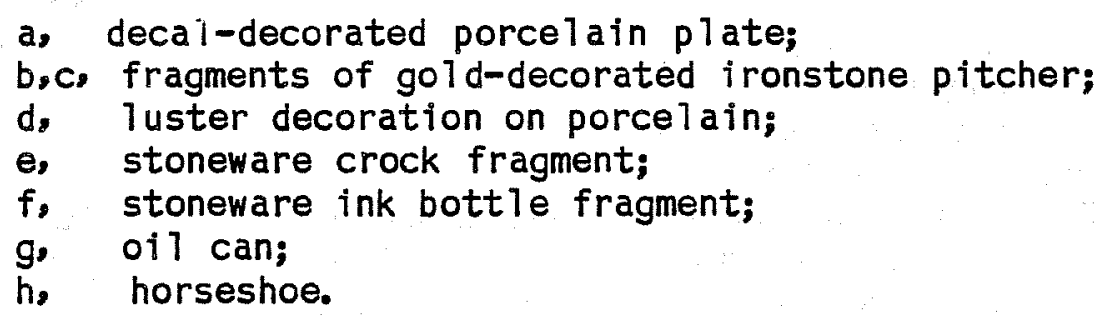




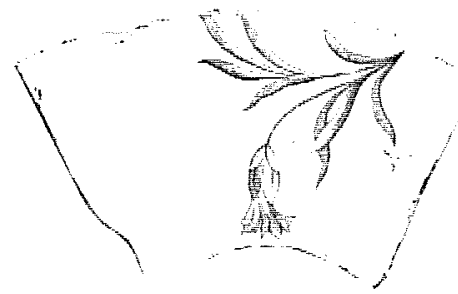

a

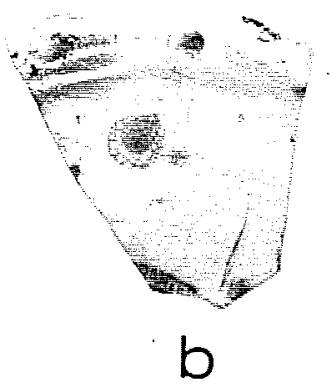

孟

d

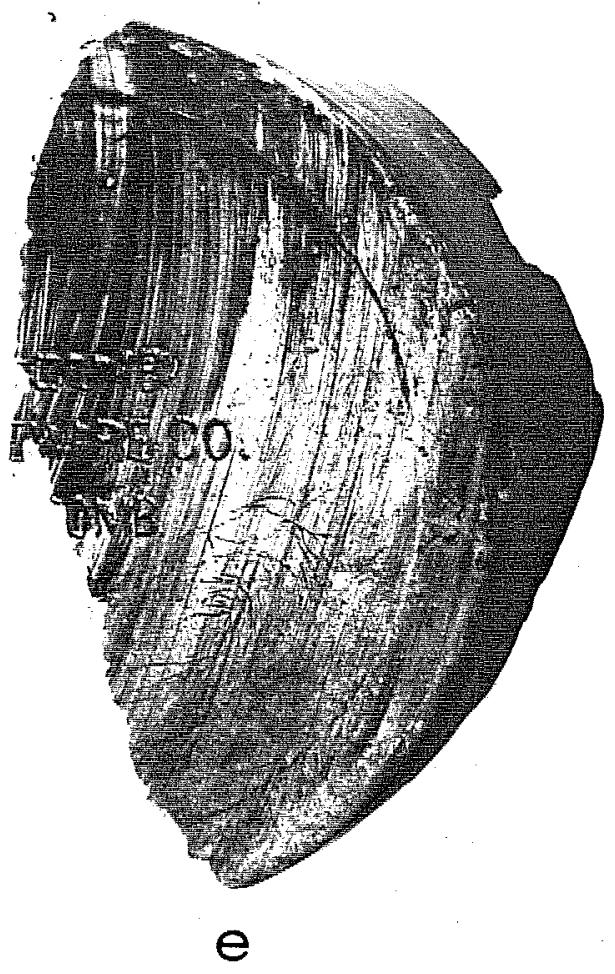

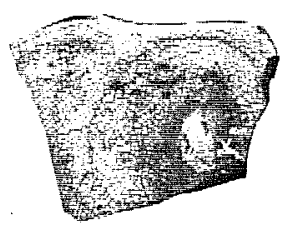

C
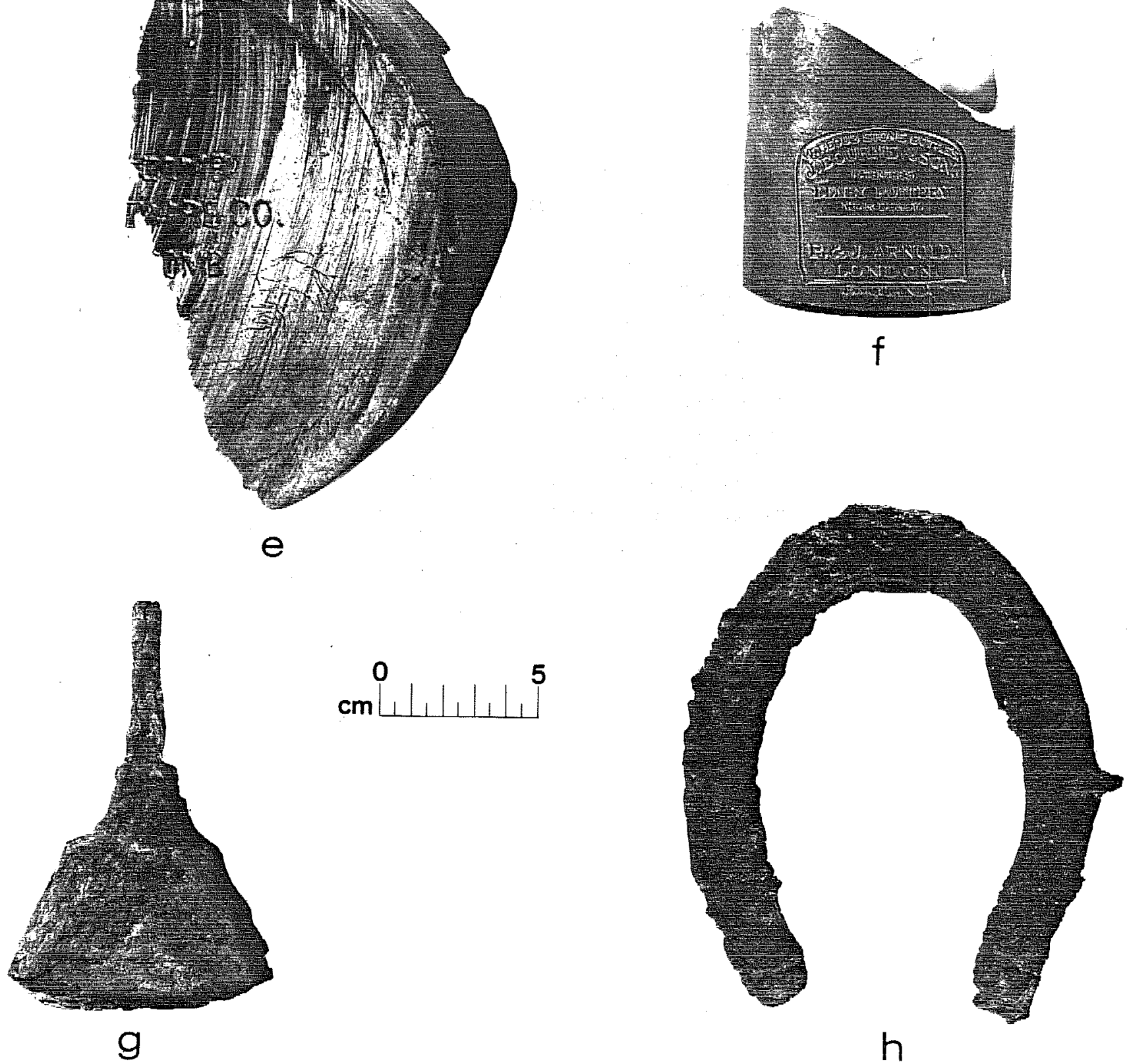
Figure 4. Selected Glass Artifacts from the Acequia Madre at the 10th Street Substation.

a, gob 1et base;

b. telephone pole insulator;

c,d, molded botties;

e, clear bottle;

f. short neck bottle with molded 1 ip;

g, condiment bottle;

$h$, long neck bottle, produced in two-piece mold;

$i$, long neck bottle, produced in turn mold;

$j$, clear milk or cream bottle;

k. brown square bottle with screw cap. 

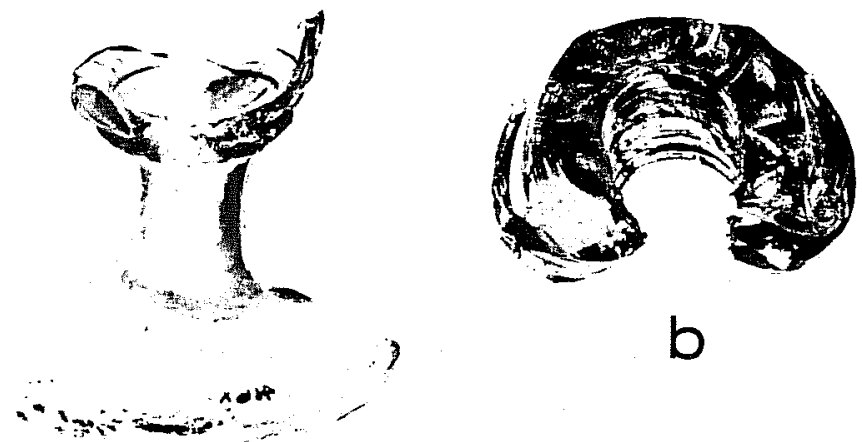

a
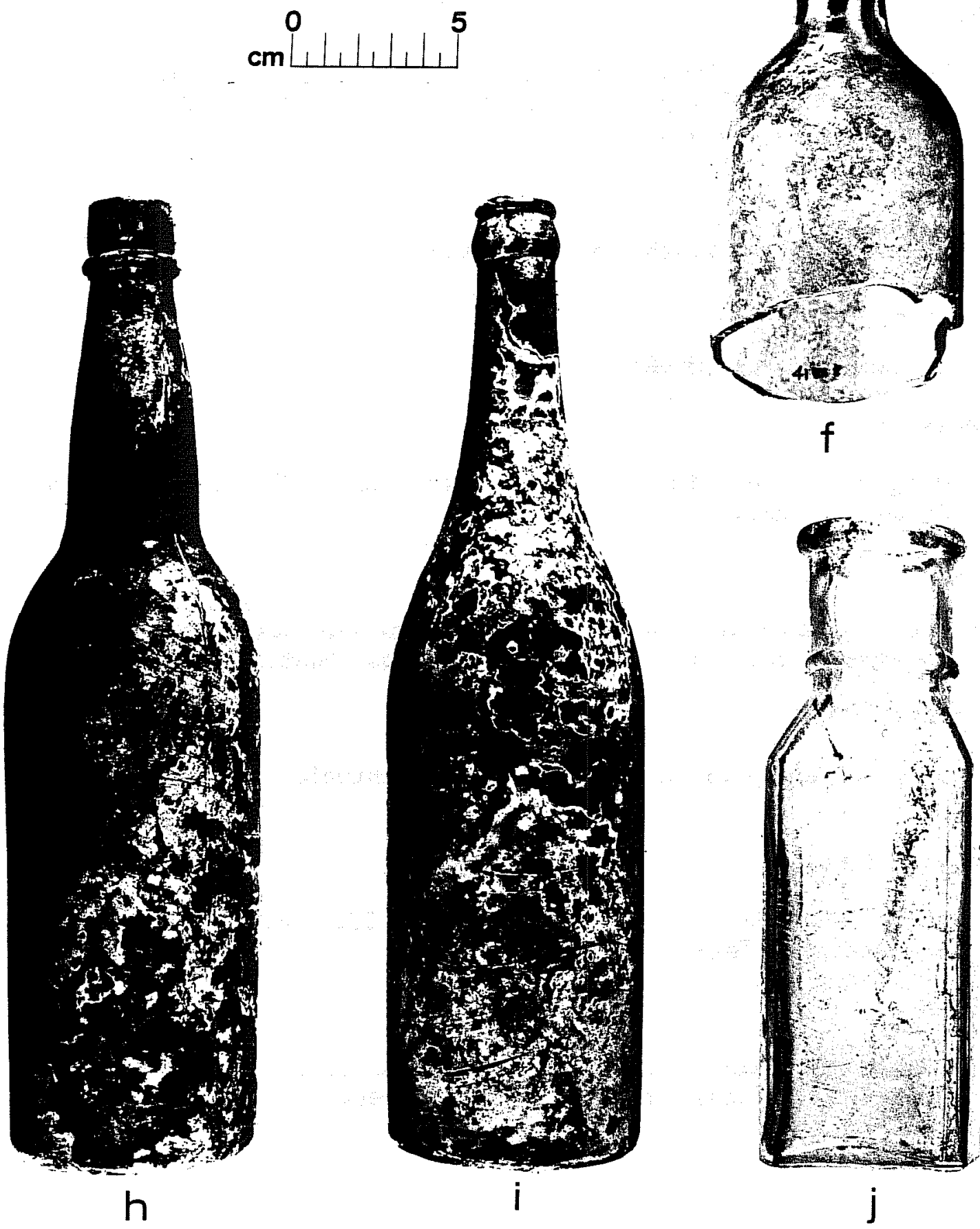
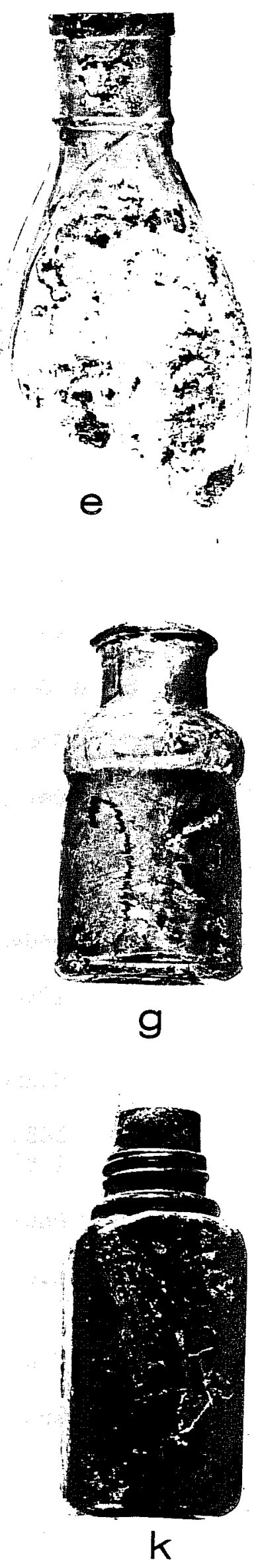
We believe the Acequia Madre meets all basic criteria needed to be eligible for nomination to the National Register of Historic Places. It is a basically intact historic feature that is known to contain cultural materials regarded as historically significant. With the same criteria we also recommend that the acequia be designated a State Archeological Landmark.

\section{REFERENCES CITED}

Adams, R. E. W. and T. R. Hester

1973 Letter to Dr. Fred Wendorf, Texas Antiquities Committee, concerning completion of excavations at Mission San Antonio de Valero, November 26.

Barker, E. E., editor

1929 Texas History. Southwest Press, Dallas, Texas.

Bexar County, Texas

Bexar County Deed Records (BCDR)

Bexar County Plats

Originals and microfilm in Bexar County Courthouse, San Antonio, Texas.

Castañada, C. E.

1936 The Mission Era; The Winning of Texas, Our Catholic Heritage in Texas. Vol. II. Von Boeckmann-Jones, Austin, Texas.

City Council Minutes (CCM)

1838- City Secretary Office, City Ha71, San Antonio, Texas.

1885

City Public Service (CPS)

n.d. 10th Street Substation. Abstract No. 15. CPS Legal Office, San Antonio, Texas.

City Public Works

1924 01d Alamo Ditch Storm Sewer, Showing Concrete Cover Between Rock Wa 1 1. Engineering Department, Sewer Office, September 18, 1924.

Everett, D. E.

1975 San Antonio, The Flavor of Its Past, 1845-1898. Trinity University Press, San Antonio, Texas. 
Fox, A. A.

1978 Archaeological Investigations of Portions of the San Pedro and Alazan Acequias in San Antonio, Texas. Center for Archaeological Research. The University of Texas at San Antonio, Archaeological Survey Report 49.

1979 A Survey of Archaeological, Architectural, and Historical Sites on the San Antonio River from 01 mos Dam to South Alamo Street and on San Pedro Creek from San Pedro Park to Guadalupe Street. Center for Archaeological Research. The University of Texas at San Antonio, Archaeological Survey Report 80.

Frkuska, A. J., Jr.

1981 Archaeological Investigations at the San Pedro Acequia, San Antonio, Texas. Center for Archaeological Research. The University of Texas at San Antonio. Archaeological Survey Report 103.

Henderson, J. and J. W. Clark, Jr.

1984 The Acequia and Other Features at Mission San Jose, Bexar County, Texas. Texas Department of Highways and Public Transportation. Highway Design Division Publications in Archaeology 25, Austin, Texas.

Ivey, J. E.

1978 Archaeological Investigations at the Gresser House (41 BX 369), San Antonio, Texas. Center for Archaeological Research, The University of Texas at San Antonio, Archaeological Survey Report 60.

Katz, P. R.

1978 Archaeological and Historical Investigations in the Arciniega Street Area, Downtown San Antonio, Texas. Center for Archaeo1ogical Research. The University of Texas at San Antonio, Archaeological Survey Report 61.

Sanborn Map and Publishing Company, Ltd.

1904 Map of San Antonio, Texas. Trinity University Archives, Trinity University Library, San Antonio, Texas.

Schuetz, M. K.

1970 Excavation of a Section of the Acequia Madre in Bexar County, Texas, and Archeological Investigations at Mission San Jose in Apri1, 1968. Texas Historical Survey Committee, Archeological Program Report 19. 
Sorrow, W. M.

1972 Archeological Salvage Excavations at the Alamo (Mission San Antonio de Valerol, 1970. Texas Archeological Salvage Project, The University of Texas at Austin, Research Report 4.

Texas Report VII

1851 City of San Antonio vs. Lewis et a1. Report of the Supreme Court of Texas, copy in City Public Service Abstract file No. 15. City Pub7ic Service Legal Office, San Antonio, Texas. 